Яремко О. П., к.е.н., начальник

Тернопільське обласне управління лісового і мисливського господарства м. Тернопіль, Україна

DOI: https://doi.org/10.30525/978-9934-26-064-3-30

\title{
НАПРЯМИ ЗБАЛАНСОВАНОГО РОЗВИТКУ ЛІСОВОГО ГОСПОДАРСТВА ПОДІЛЬСЬКОГО ЕКОНОМІЧНОГО РЕГІОНУ
}

Лісові ресурси Поділля служать основою економічної системи ведення лісового господарства. За рахунок використання лісових ресурсів лісове господарство отримує кошти для відтворення лісів, проведення лісівничих та лісоохоронних заходів, відіграє основну роль для збалансованого розвитку лісового господарства [1].

Подільський економічний регіон має вигідне економікогеографічне положення, що визначається його розташуванням 3 промислово розвиненим центральним регіоном та Поліським, Карпатським, Південним економічними регіонами та Республікою Молдовою. Регіон визначається виробництвом товарів народного споживання, вирощуванням продукції сільського господарства, харчової, легкої, деревообробної, целюлознопаперової промисловості та будівельних матеріалів. Видову структуру лісів Поділля формують дубово-грабові ліси на півночі та букові ліси в межах регіону. Даний регіон є досить малолісний але забезпечений сприятливими грунтово-кліматичними умовами для ведення лісового господарства, близько 90\% площі дібров державного лісового фонду розташовані на території Поділля. Одним, 3 головних завдань лісівників регіону $є$ вирощування цінних дубових насаджень. Основу лісової та деревообробної промисловості Подільського економічного регіону складають кінцеві етапи деревообробки, а саме виробництво будівельних деталей, меблі, папір. Удосконалення лісопереробної промисловості в Подільському регіоні є необхідним етапом, в першу 
чергу, у підвищенні продуктивності лісів та лісогосподарської діяльності. Напрями удосконалення лісової галузі регіону необхідно розглядати в контексті збалансованого розвитку лісокористування [2].

Насамперед, варто забезпечити екологічно орієнтований напрямок ведення лісового господарства та комплексного використання лісових ресурсів, 3 урахуванням ландшафтних особливостей та перегляд принципів розподілу лісів за екологічним і господарським призначенням.

Впровадження лісової сертифікації на території регіону надає змогу оцінити відповідність лісового господарства до міжнародних екологічних, соціальних і економічних вимог. Станом на початок 2021 року площі лісової сертифікації Подільського регіону збільшуються. Лідером є Тернопільська область де вже сертифіковано 147807,0 га площ лісових ділянок, Хмельницька область має 186 482,5 га сертифікованих лісів та Вінницька 133870,0 га [3].

Ключову роль в забезпеченні сталого розвитку лісового господарства відіграє результативний управлінській підхід, що надає рівні умови на кожному етапі лісогосподарського виробництва. Як вже зазначалось, Подільський економічний регіон вирізняється саме деревообробною галуззю, тому необхідно розглядати комплексну модель взаємодії стейкхолдерів для ефективного управління лісогосподарського виробництва в умовах сталого розвитку (рис. 1). Зацікавленість в процесі розвитку лісогосподарської діяльності регіону всіх соціальноекономічних сторін забезпечить довгостроковий результат.

Отже, для забезпечення збалансованого лісокористування, збереження біорізноманіття та застосування нових інноваційних підходів, необхідно виокремити основні напрями сталого розвитку для лісової галузі Подільського економічного регіону.

Поетапне застосування ведення практики виконання лісогосподарських робіт підприємствами малого та середнього бізнесу 3 лісогосподарськими підприємствами забезпечить фінансування та конкурентоспроможність. Також, має бути на 
меті впровадження сучасних технологій у лісовирощуванні для збільшення видового складу та заліснення площ.

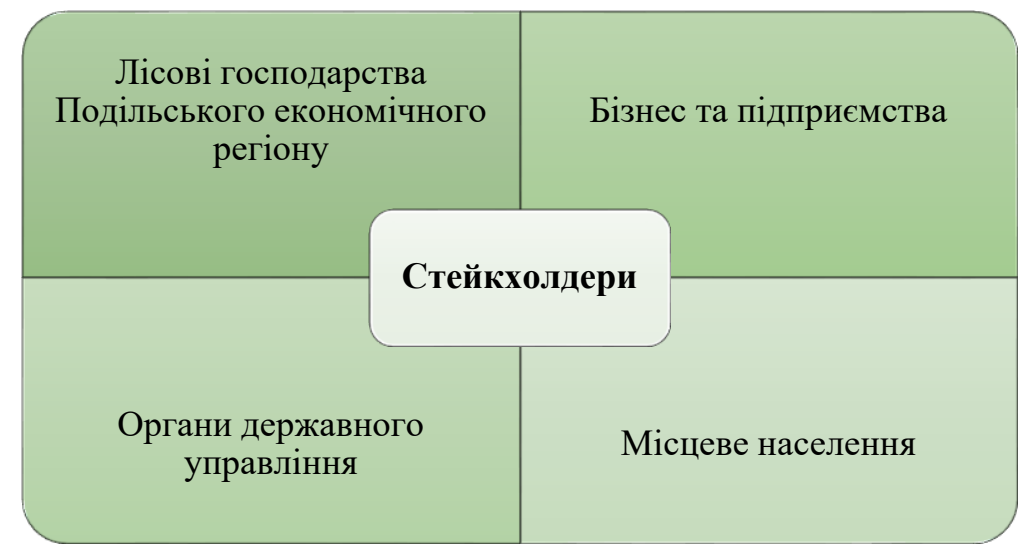

\section{Рис. 1. Основні учасники забезпечення ефективного збалансованого розвитку лісового господарства}

Джерело: розроблено автором

Розвиток економічного стимулювання лісогосподарських заходів підвищить показники ефективності лісогосподарської діяльності, але треба зауважити, що без розробки регіональної та місцевих програм ці кроки будуть неефективними. Потрібно враховувати всі загрози та можливі ризики та вдосконалювати лісовпорядкування і систему планування лісогосподарської діяльності [4].

\section{Література:}

1. Ведення лісового господарства на засадах сталого розвитку: Тернопільське обласне управління лісового господарства. URL: https://ternopillis.gov.ua/dijalnist/vedennja-lisovogo-gospodarstva-na-zasadakh-stalogo-rozvitku.html

2. Подільський економічний регіон: Українські кластери. URL: https://ucluster.org/universitet/klastery-ukraina/2005-study/podillya-economic-region.

3. Факти та цифри: Forests For All Forever. URL: https://ua.fsc.org/uaua/nasha-diyalnist/facts_and_figures 
4. Стратегія сталого розвитку та інституційного реформування лісового господарства України на період до 2022 року. URL: https://assomebli.files.wordpress.com/2012/03/d181d182d180d0b0d182d0b5d0b3d196d 18f_-d0bed181d182d0b0d182d0bed187d0bdd0b8d0b9-010917-d0bdd0b0-d0bc-d0b0d0bf11391.pdf 